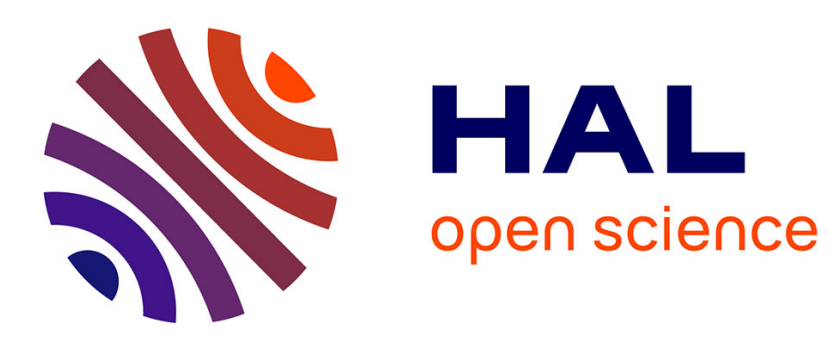

\title{
Cenozoic to Cretaceous paleomagnetic dataset from Egypt: New data, review and global analysis
}

\author{
Mireille M. Perrin, Ahmed Saleh
}

\section{To cite this version:}

Mireille M. Perrin, Ahmed Saleh. Cenozoic to Cretaceous paleomagnetic dataset from Egypt: New data, review and global analysis. Earth and Planetary Science Letters, 2018, 488, pp.92-101. 10.1016/j.epsl.2018.02.014 . hal-02109229

\section{HAL Id: hal-02109229 \\ https://hal.science/hal-02109229}

Submitted on 30 Apr 2019

HAL is a multi-disciplinary open access archive for the deposit and dissemination of scientific research documents, whether they are published or not. The documents may come from teaching and research institutions in France or abroad, or from public or private research centers.
L'archive ouverte pluridisciplinaire HAL, est destinée au dépôt et à la diffusion de documents scientifiques de niveau recherche, publiés ou non, émanant des établissements d'enseignement et de recherche français ou étrangers, des laboratoires publics ou privés. 


\section{CENOZOIC TO CRETACEOUS PALEOMAGNETIC DATASET FROM EGYPT:} NEW DATA, REVIEW AND GLOBAL ANALYSIS

Mireille Perrin ${ }^{1}$ and Ahmed Saleh ${ }^{2}$

${ }^{1}$ Aix-Marseille Univ, CNRS, IRD, Coll France, CEREGE, Aix en Provence, France.

${ }^{2}$ National Research Institute of Astronomy and Geophysics, Egypt.

Corresponding author: perrin@ @erege.fr ; +33 634323123

\section{Abstract}

Different phases of igneous activity took place in Egypt during the Mesozoic and the Cenozoic and oriented samples were collected from three Cenozoic localities (Baharya oasis in the Western Desert, Abu Had in the Eastern Desert and Quseir along the Red Sea coast), and four Cretaceous localities (Toshki \& Abu Simbel south of Aswan, and Shalaten \& Abu Shihat along the Red Sea coast). Rock magnetic properties of the samples indicate magnetite and titanomagnetite as the main carrier of the remanent magnetization. Following stepwise demagnetization, characteristic remanent directions were identified only for $62 \%$ of the samples, a fairly low rate for that type of samples, and 8 new paleomagnetic poles were calculated. All our Cenozoic poles fall clearly off Master Polar Wander Paths proposed for South Africa. Therefore, all paleomagnetic results, previously published for Egypt, were compiled from Cretaceous to Quaternary. The published poles largely overlap, blurring the Egyptian Apparent Polar Wander Path. A new analysis at the site level was then carried out. Only poles having a kappa larger than 50 were selected, and new pole positions were calculated by area and by epoch, when at least 3 sites were available. Even though the selection drastically reduced the number of considered poles, it allows definition of a reliable Cenozoic apparent polar wander trend for Egypt that differs from the South African Master Polar Wander Path by about $10-15^{\circ}$. If the Cretaceous igneous poles are in good agreement with the rest of the African data, the sedimentary poles plot close to the Cenozoic portion of the South African 
Master Polar Wander Path, a discrepancy that could be related either to inclination flattening and/or error on age and/or remagnetization in the Cenozoic.

Key words: Paleomagnetism, Cenozoic, Cretaceous, Egypt

\section{Introduction}

During the Phanerozoic, Egypt was affected by intermittent igneous activity, mainly in relation with the Late Precambrian fracture system. A compilation of more than 150 isotopic ages ( $\mathrm{Rb} / \mathrm{Sr}$ with a few K/Ar) was used to construct a sequence of Phanerozoic igneous activity in Egypt (Meneisy, 1990): i) Early Paleozoic vulcanicity associated with or closely related to the Pan-African tectono-thermal event; ii) Late Paleozoic magmatism related to the initial break-up of Pangea and the closure of the Tethys; iii) Mesozoic igneous activity related to the rifting of the South Atlantic, the corresponding Africa-South America compression and Afro-Arabian strike slip faulting; iv) Cenozoic volcanic pulses associated with the Red Sea opening; and v) Quaternary igneous activity, not very well documented, that could be of early Pleistocene age along the Red Sea and in the south Western Desert.

It is often difficult to decipher between the different episodes and, in the absence of radiometric dating, paleomagnetism is a very convenient tool to estimate the age of an intrusion or an extrusion. Paleomagnetic data can further constrain the local and global tectonic activity in the area. Although there have been many paleomagnetic studies undertaken in the past century, the definition of an apparent polar wander path is not straightforward for Egypt and new Cretaceous and Cenozoic samples were collected in order to improve the quantity and quality of paleomagnetic information from this region. All samples were drilled in the field using a gasoline-powered drill and oriented using both magnetic and sun compasses. 


\section{Cretaceous igneous activity and sampling}

Mesozoic igneous activity resulted in the intrusion and/or extrusion of various types of rock, abundant and diversified in size, form and composition. The basaltic rocks and alkaline ring complexes can generally be related to two main phases of igneous activity: i) a Late

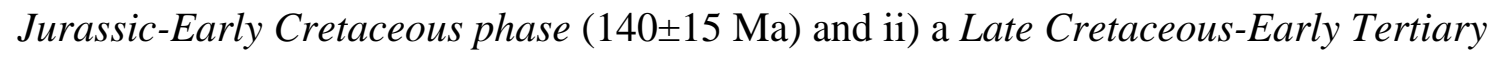
phase $(90 \pm 20 \mathrm{Ma})$. Most of the Mesozoic igneous activity is located in the southern Eastern and Western Deserts and in Sinai (Meneisy, 1990).

Most samples related to the Late Jurassic-Early Cretaceous phase are alkaline ring complexes from the south Eastern Desert. This 140 Ma episode of alkaline magmatism in Egypt coincided with a major episode of alkaline magmatism occurring in the areas surrounding the South Atlantic and related to the initial rifting of Africa from South America. Ring complexes of the same age have also been reported in northeastern Sudan. Examining the tectonic distribution map of the ring complexes in the south Eastern Desert, it can be noted that these complexes are confined to a slightly curved zone of weakness that extends $200 \mathrm{~km}$ and trends in a NE direction parallel to the Aswan trend, the regional fault system of Wadi Halfa, Aswan, and Marsa Alam. The generation of this magma may have been triggered by some "hot spot" mechanism.

The Late Cretaceous-Early Tertiary phase is perhaps one of the most documented events of alkalic igneous activity in Egypt, formed during large scale strike-slip faulting in Afro-Arabia. The best record of the event is undoubtedly the volcanic rocks of Wadi Natash, about $125 \mathrm{~km}$ ENE of Aswan, along the boundary between the Nubian sandstone and the Precambrian basement complex, for which a mantle-plume source has been suggested (Mohamed, 2001). In the south Western Desert, some alkaline volcanics that pierce Paleozoic sandstones can be correlated to the Wadi Natash volcanics (Oweinat and Gilf El Kebir areas). 
The same alkaline magmatism gave rise to Gebel El Kahfa, Gebel Abu Khrug, and partly Gebel El Naga and Gebel Mansouri ring complexes.

Different localities, supposed to be Cretaceous in age, were sampled south of Aswan and along the Red sea (Figure 1): 3 sites (29 samples) in Toshki area $\left[22.78^{\circ} \mathrm{N}, 31.48^{\circ} \mathrm{E}\right]$ and 3 sites (26 samples) north of Abu Simbel city [22.43ㅇ, $\left.31.21^{\circ} \mathrm{E}\right]$, in the south Western Desert; 21 dikes (122 samples) in the wadi Abu Shihat, along the Red Sea; and 4 flows (25 samples) close from Shalaten $\left(23.12^{\circ} \mathrm{N}, 35.46^{\circ} \mathrm{E}\right)$. As isotopic ages are missing, the age of the basaltic rocks was based on field relations, within wide error limits, and therefore has to be taken with caution.

\section{Cenozoic igneous rocks and sampling}

Several volcanic events took place during the Cenozoic, the earliest of Paleocene age being the continuation of the extensive late Cretaceous igneous activity. Mid Tertiary volcanism is widespread, with several pulses in the Late Eocene (Red Sea doming and extension) followed by phases related to the opening of the Red Sea and Gulf of Suez and ranging in age from Late Oligocene to Middle Miocene (Meneisy, 1990). This volcanism is uniformly basaltic and widely distributed in the northern part of Egypt and in Sinai. Basaltic extrusives cover a large area beneath the Nile delta and adjacent parts of the Western Desert. Isolated outcrops also occur along the Fayum-Rawash, and Cairo-Suez stretches. In the south

Western Desert, some Tertiary basaltic occurrences are sparsely distributed, associated sometimes with minor occurrences of acid to alkaline rocks. Along the Red Sea coast, south of Quseir, some dolerite flows occur. A few scattered basaltic dykes and plugs intruding Nubian sandstones in the south Eastern Desert are also considered of Tertiary age. Finally in Sinai, several Tertiary basaltic outcrops occur, especially in the western and central areas. 
The Tertiary basaltic rocks are found mainly in the form of sheets, dikes, sills, widening sometimes into plugs, cinder cones or small ridges. The basalts of Abu Zabel, Abu Rawash, Djebel Qatrani, and the Cairo-Suez district are described as quartz tholeiitic basalt whereas the basalts from Baharya Oasis and the Nile district are alkali olivine basalts. Trace elements abundances and $\mathrm{Sr}-\mathrm{Nd}-\mathrm{Pb}-\mathrm{Hf}$ isotopic signatures are consistent with contributions from two distinct source regions, one similar to the Afar plume and the other analogous to the rejuvenated Pan-African lithosphere that likely underlies most of the continent (Endress et al, 2011).

Using K/Ar on whole rock ages, Meneisy (1990) proposed different volcanic episodes: i) Late Eocene-Early Oligocene $(40 \pm 10 \mathrm{Ma})$ possibly due to emergence related to a shallowing of the Tethys, and volcanics developing along the fracture systems associated to these tectonically-controlled movements, in the south Western Desert (Gebels Oweinat, Arkenu, Kamil, Darb El Arbain); ii) Oligo-Miocene phase (24+2 Ma) related to the opening of the Red Sea - the Red Sea formed by continental rifting in the Late Oligocene or Early Miocene and widened through a combination of normal faulting and of dike injection - well documented in northern Egypt (in the north Western Desert at Wadi Samalut and Gebel Qatrani, in Cairo-Suez area, mainly at Abu Zabel, and along the Red Sea, south of Qusier) and in western Sinai (Gebels Matulla and Araba); and iii) Lower-Middle Miocene phases (20, 18 and $15 \mathrm{Ma}$ ) as in Baharya Oasis.

More recently, ${ }^{40} \mathrm{Ar} /{ }^{39} \mathrm{Ar}$ dating confirms the short duration of the Oligo-Miocene phase in the Cairo-Suez area, with ages indistinguishable from those of early syn-rift Red Seaparallel dikes in western Arabia, Sinai and the Eastern Desert of Egypt. This suggests that the Red Sea propagated through Arabia/Sudan as a single, very rapid pulse and only stopped et the interface with stronger Neotethyan oceanic crust near the coast of the modern Mediterranean Sea. Although the volcanism of northern Egypt is volumetrically smaller than 
that of Afar, it has been proposed (Bosworth et al, 2015) that it played a similar role as a trigger for a large-scale rift event, with a Cairo mini-plume. The age of the igneous activity of the Baharya Oasis was found to be similar to the rest of the Oligo-Miocene phase $\left({ }^{40} \mathrm{Ar} /{ }^{39} \mathrm{Ar}\right.$ ages between 21-25 Ma, Bosworth et al, 2015), questioning the existence of the last volcanic phase of Meneisy (1990).

During previous field work, different localities have been already sampled in the OligoMiocene phase (Perrin et al, 2009): 2 flows (27 samples) at Abu Zabel $\left(30.28^{\circ} \mathrm{N}, 31.36^{\circ} \mathrm{E}\right)$ north of Cairo; 3 flows (23 samples) around Quatrani $\left(29.71^{\circ} \mathrm{N}, 30.65^{\circ} \mathrm{E}\right)$ in the Fayum district; and 3 sites (18 samples) in Wadi Nukhul $\left(29.02^{\circ} \mathrm{N}, 33.16^{\circ} \mathrm{E}\right)$, western Sinai. All these basalts yielded ${ }^{40} \mathrm{Ar} /{ }^{39} \mathrm{Ar}$ age around $23 \mathrm{Ma}$ (Kappelman et al, 1992; Bosworth et al, 2015). New sampling was carried out in three other localities: 3 sites (13 samples) in the Baharya Oasis area $\left(28.36^{\circ} \mathrm{N}, 28.88^{\circ} \mathrm{E}\right)$; 4 flows (28 samples) in Wadi Abu El Had $\left(28.03^{\circ} \mathrm{N}\right.$, $\left.32.35^{\circ} \mathrm{E}\right)$, north Eastern Desert; and 5 dikes (35 samples) close from Quseir $\left(25.75^{\circ} \mathrm{N}\right.$, $\left.34.39^{\circ} \mathrm{E}\right)$, along the Red Sea.

\section{Temperature dependence magnetic susceptibility}

Temperature dependence magnetic susceptibility is a quick and sensitive method for the identification of magnetic phases and for the determination of titanomagnetite composition (Lattard et al 2006). Furthermore, the degree of reversibility of the heating and cooling runs allows an estimate of phase changes, which can be interpreted in terms of stability of the original magnetic phases (Vahle et al., 2007). Low-field thermomagnetic measurements (K-T curves) under controlled atmosphere were carried out on selected samples for all sites using a CS-3 apparatus coupled to a KLY-3 bridge (AGICO, Czech Republic). Samples were progressively heated from room temperature (RT) up to $600^{\circ} \mathrm{C}$ and subsequently cooled back 
to RT. For most samples, low-temperature susceptibility (from about $-195^{\circ} \mathrm{C}$ to $\mathrm{RT}$ ) was also recorded using a CS3-L apparatus coupled to the KLY-3 bridge.

The five associations, seen in our samples, are illustrated by representative K-T curves (Figure 2):

a) One-fourth of our samples display a single magnetic carrier with a high Curie point (Tc around $550-575^{\circ} \mathrm{C}$ ) and a good reversibility between the heating and cooling curves. This is typical of the presence of almost pure magnetite (Ti-poor magnetite). If this behavior was seen in some Cenozoic samples of Abu Zabel, here it is only found in the Cretaceous basalts of Abu Shihat and Shalaten;

b) Besides the Ti-poor magnetite, another carrier of magnetization is also present in onethird of the samples. The lower Tc $\left(350-400^{\circ} \mathrm{C}\right)$ and the significant irreversibility between heating and cooling curves point to titanomaghemite that get transformed at higher temperature. This association is present in Cenozoic (Qatrani and Baharya flows), and Cretaceous (Abu Shihat dykes and Shalaten flows) sites.

c) Samples from Abu Had are even more complex, with three magnetic phases: i) Ti-rich magnetite with low $\mathrm{Tc}\left(100-150^{\circ} \mathrm{C}\right)$ and reversible curves; ii) Ti-maghemite with intermediate $\mathrm{Tc}\left(390-420^{\circ} \mathrm{C}\right)$ and a significant irreversibility; and iii) Ti-poor magnetite with high $\mathrm{Tc}\left(500-550^{\circ} \mathrm{C}\right)$.

d) Another third of our samples contain a mixture of Ti-rich magnetite and the Timaghemite. If the irreversibility of the curves is taken as a qualitative measure of the degree of maghemitization, most of our samples display relatively small degrees of maghemitization, a characteristic feature of the basaltic rocks. This behavior is present in Cenozoic and Cretaceous sites (Baharya, Toshki, Abu Simbel, Shalaten). 
e) Finally, some samples from the south Western Desert (Toshki and Abu Simbel) carry mostly the Ti-rich magnetite phase with Tc below $200^{\circ} \mathrm{C}$ and no other phases at higher temperatures.

\section{Paleomagnetic analysis}

One specimen from each core was stepwise demagnetized using alternating fields (AF), up to a maximum of $170 \mathrm{mT}$ with an automated degauss system coupled with a $2 \mathrm{G}$

Superconducting Rock Magnetometer, or thermal demagnetization up to $600^{\circ} \mathrm{C}$ with an homemade oven. Characteristic Remanent Magnetizations (ChRM) were calculated using principal component analysis with Maximum Angular Deviation (MAD) always below 4, and their means estimated by Fisher's statistic ( $\alpha_{95}$ and kappa). It is worse being reminded that, if kappa is independent of the number of sites $\mathrm{N}$ and always reflects the dispersion of a population around the mean, $\alpha_{95}$ is meaningless for very small population and will not be given in the tables for $\mathrm{N}<5$. Demagnetization diagrams were done with the PuffinPlot software (Lurcock and Wilson, 2012), and the analysis with the help of the PmagPy software (Tauxe et al, 2016). Considering the latitudes of our sites, the inclination of the present dipole field (PDF) can be estimated between $47^{\circ}$ for the northern sites (Baharya, Abu Had) and $40^{\circ}$ for the southernmost sites (Toshki, Simble, Shalaten).

All samples from Qusier plugs are characterized by an intensity of their Natural Remanent Magnetization (NRM) a thousand times lower than all other samples, a very large dispersion of their NRM directions, and completely erratic AF demagnetizations that do not isolate a ChRM. Very likely sulfurs related to some phase(s) of metamorphism are the magnetic carriers in these samples that will not be considered any further.

After removal of a viscous component in the present field, all Baharya oasis (BH) basalts present a reverse ChRM with unblocking fields ranging from 10-30mT to $25-60 \mathrm{mT}$ 
(e.g. Figure 3a). At the end of the demagnetizations, spurious component of magnetizations can be acquired, maybe related to transformation of Ti-maghemite at high temperature or through gyromagnetic remanence or a higher sensitivity to anhysteretic remanent magnetization at the end of AF demagnetization. Dispersion at the site level is fairly high but without relation to the sites (Figure 4a). However, the specimen mean value is within $1^{\circ}$ of the site mean (Table 1) and was favoured considering the small number of sites.

The magnetic behaviour of the Toshki (TK) basalt is the most simple found in this study, with mostly one component of magnetization (e.g. Figure 3b), carried by Ti-rich magnetite. The ChRMs calculated from TK1 and TK3 seem statistically different from those of TK2 (Figure 4e) but both site and specimen means are still within one degree.

After removal of a secondary component that is either viscous or a partial IRM overprint, the ChRM carried by most samples of Abu Simble (AS) is easy to define (e.g. figure 3a). However, the ChRM directions are very dispersed, as well at the site level than at the locality (Figure 4f), especially in inclination. This dispersion cannot be explained by analytical uncertainties, but is more likely related to an orientation problem with samples not really in place that was difficult to see with the outcrops buried in the desert sand. The hypothesis is supported by the close agreement between the Toshki and the Abu Simbel mean results, apart only by $3.5^{\circ}$.

During AF demagnetization, all basalts sampled in wadi Abu Had (AH), from Abu Shihat (SH) dykes and Shalaten (ST) basalt present two components of magnetization as illustrated by Figure 3c. The low coercivity components are more or less pronounced, but always removed in fields between 5-15mT and almost randomly distributed. This points to an isothermal process for the acquisition of these secondary components, likely during lightning strikes. However, at higher fields or temperatures, reverse ChRMs can be isolated from most of the samples. The dispersion is fairly large for Abu Had (Figure 4d), likely because of 
imprecisions on the definition of the final components that can represent sometime less than

$2181 \%$ of the NRM (e.g. close-up of the end of the orthogonal diagram on figure $3 \mathrm{c}$ ). However,

219 the reliability of the mean value is supported by the agreement here also within $1^{\circ}$ between

220

221

specimen mean and site mean (Table 1). Shalaten samples give a reverse ChRM fairly well grouped at the site level (Figure 4h) and significantly different from the recent field. Abu Shihat site means cluster around the present dipole field position (Figure 4g).

Mean ChRM directions are presented by site (Figure 5a) and by area (Figures 5b), and the corresponding Virtual Geomagnetic Pole (VGP) positions (Table 1) are compared with two Master Polar Wander Paths (MPWP) for South Africa (BC2002: Besse and Courtillot, 2002; T2008: Torsvik et al, 2008; Figure 5c).

Even though the two MPWPs are fully comparable for the period 0-130Ma of interest for our study, all our Cenozoic pole positions are clearly off the paths. The Cretaceous poles from Toshki TK, Abu Simbel AS and Shalaten ST1 are in good agreement with the MPWP but not the poles from Shalaten ST2 and Abu Shihat SH and SH10. If the reliability of poles ST, AS, and SH can be questioned (only one site or kappa <50), all other poles are robust.

\section{Comparison with previously published data}

In order to better understand this discrepancy, all Cenozoic and Cretaceous paleomagnetic data published for Egypt were searched. 41 references published between 1973 and 2016 were found but full text could be retrieved only for 33 of the references. In some cases, the same data was published in different papers and only the most recent one was considered. Altogether, 57 poles from 27 papers were compiled (33 Cenozoic poles and 24

Cretaceous poles, Table 2, Figure 6a). After a mild selection (kappa >50), the 50 remaining poles (29 Cenozoic poles and 21 Cretaceous poles, Figure 6b) present a significant dispersion but mainly a fairly large overlap between the Cenozoic and Cretaceous poles with no obvious 
correlation between VGPs and ages. Different reasons can be evoked to explain that distribution. The first one is obviously related to dating uncertainties and unfortunately not much can be done besides getting new, reliable radiochronologic ages. Another important reason is clearly related to remagnetization and possible estimates of intermediate components of magnetization, as shown with our data. Finally there is a real problem of data averaging, with some areas that have been extensively sampled. In order to check the influence of these last two factors, a compilation was made at the site level for all data with ages ranging from Miocene to Cretaceous.

\section{Compilation of the Cenozoic data at the site level}

Site means could be retrieved from all papers except three references (El Shazly and Krs, 1973; Lofty, 1998; Kent and Dupuis, 2003) that will therefore not be included in the following analysis. Altogether, 247 sites (145 igneous and 102 sediments, Table 3) are available for the period 14-59 Ma, mainly in the northern part of Egypt (Figure 1) but with a fairly good temporal distribution, except maybe for the Paleocene ( 5 poles per Ma in average; Figure 7a). However, when all site means are considered, the dispersion is extremely large (Figure 7b).

A large part of that dispersion is related to the Shalaten data. Niazzi and Mostafa (2002) proposed 4 distinct populations (G1 to G4) for their Shalaten data: the G1 group supposed to be compatible with their geological and geochronological data, that would confirm the Early Miocene age around $20 \mathrm{Ma}$; the other groups being structurally affected by the Red Sea opening. However, looking at the almost random dispersion of the site mean directions, with usually pretty tight site distributions (Figure 7c), and our own results on the same area of the Red Sea coast (Figures 3c and 4g), the hypothesis of a remagnetization of these isolated hilly masses by lightning strikes is more likely. 
Removing the 39 igneous sites from Shalaten (Niazzi and Mostafa, 2002), as well as our two Shalaten sites and all site means with kappa $\leq 50$, the dispersion of the remaining 134 sites (64 sedimentary, 70 igneous) is drastically reduced (Figure 7d). However the overlapping of the remaining site poles is still large, with a slight difference between results obtained from igneous and sedimentary rocks. Different types of averaging of the whole dataset have been tempted (e.g. 5 or $10 \mathrm{Ma}$ window) but none can clarify the APWP likely because of age uncertainties, but also because all intermediate components were not removed by selecting $\mathrm{k}>50$ and maybe from an over-representation of certain areas.

In order to test the influence of the over-representation of certain areas, a new analysis was carried out with all sites, including our new sites, having a kappa larger than 50 . When in a given area, and for a given period, at least 3 poles were available, a new mean VGP was calculated (Table 4, Figure 7e). In locations where many different studies have been published (Baharya, Cairo and Qatrani, Table 2), the new analysis drastically reduced the number of means but really improves the definition of the proposed poles (Table 4). Cairo and Qatrani areas are very good example of what we called 'over-representation' of data: 10 and 9 poles

were respectively published (Table 2), and only 2 and 3 poles are now proposed (Table 4 ). In areas where only one publication per locality was available (Minia, Qatara and Mokatam), it basically confirms the published determinations, with a slight improvement related to the rejection of sites with $\mathrm{k} \leq 50$. Finally for some areas (Oweinat, Tereifiya, and Gilf Kebir), no VGPs could be estimated.

The four recalculated sedimentary poles (Table 4) describe a coherent evolution toward the present field even though the relation between poles and ages remains unclear. This can be explained by the averaging at a given site of sediments of slightly different ages (sections). Averaging the site poles for individual sedimentary units, with a roughly 10Ma age windows, give a better definition of the mean poles for the different epochs of the Cenozoic: 
- $\quad$ Lower Miocene (12-23Ma), 9 sites, $202^{\circ} \mathrm{E}, 77^{\circ} \mathrm{N}, \mathrm{A}_{95}=1.6, \mathrm{~K}=983$

- Oligocene $(23-34 \mathrm{Ma}), 9$ sites, $157^{\circ} \mathrm{E}, 76^{\circ} \mathrm{N}, \mathrm{A}_{95}=6.1, \mathrm{~K}=71$

- Upper Eocene (34-40Ma) 20 sites, $159^{\circ} \mathrm{E}, 72^{\circ} \mathrm{N}, \mathrm{A}_{95}=4.3, \mathrm{~K}=59$

- Lower Eocene (40-53Ma), 26 sites, $159^{\circ} \mathrm{E}, 69^{\circ} \mathrm{N}, \mathrm{A}_{95}=4.1, \mathrm{~K}=49$

The corresponding apparent polar wander path (APWP) for Egypt is highlighted in Figure 7e by a dashed arrow. Despite a discrepancy between the lower Miocene poles, the Oligocene and Eocene new igneous poles (Table 4, Figure 7e) are in good agreement with the sedimentary data, comforting the reliability of the proposed path, and its clear difference from the BC2002 MPWP (Figure 7e). An anticlockwise rotation on the order of $10-15^{\circ}$ is necessary to bring back the Egyptian curve onto the South African MPWP. The Cenozoic collision of continental Africa and Eurasia during the closure of the Neo-Tethys Ocean altered the kinematic and tectonic evolution of the Africa plate, including a slowdown in Africa's northward motion relative to its surrounding plates (DeMets and Merkouriev, 2016) and an accompanying fragmentation of the plate into distinct Arabia, Nubia and Somalia plates. However, fragmentation of the African plate seems to have begun at 29-24 Ma, when incipient rifting along the present Gulf of Aden and Red Sea signalled the break-off of the Arabian peninsula from Africa (Bosworth and Stockli, 2016). Therefore the observed difference between the Egyptian and South African polar wander path seem difficult to be explain solely by the opening of the Red Sea, except if the fragmentation started in the Eocene. However, a similar anticlockwise rotation of $11^{\circ}$ has been observed (Ibrahim, 1999) from paleomagnetic poles of the Afar area.

\section{Compilation of the Cretaceous data at the site level}

Site means could be retrieved from all papers except for one reference (El Shazly and Krs, 1973) that will therefore not be included in the following analysis. Altogether, 224 sites 
314 (118 igneous and 106 sediments, Table 3 and Figure 8a) are available for the Cretaceous

315 (around 3 data/Ma), mainly in the southern part of Egypt (Figure 1). Using the same selection

316 criteria than for the Cenozoic (kappa>50), the number of poles is roughly cut by half but the

317 dispersion of the remaining 103 sites (72 igneous, 31 sedimentary, Figure $8 \mathrm{~b}$ ) is significantly

318 reduced. When the igneous site poles have a fairly isotropic distribution, there is a clear trend

319 in the sedimentary results.

320 As for the Cenozoic, all site results have been reanalysed by areas and by period. Only

321 four igneous and four sedimentary poles (Table 4, Figure 8c) pass the selection criteria (at

322 least 3 sites and $\mathrm{K}>50$ ). All igneous Cretaceous poles are in good agreement with the 78-98

323 Ma portions of the Besse and Courtillot (2002) MPWP for South Africa (BC2002),

324 underlying a Late Cretaceous age for all this volcanic activity (Late Cretaceous-Early Tertiary

325 phase). Sedimentary poles fall close from the Cenozoic portion of BC2002. Considering the

326 trend seen in the distribution of the site determinations (Figure 8b), an inclination problem

327 could be suspected. The elongation/inclination E/I method (Tauxe et al, 2008) was used to try

328 to recognize a possible inclination flattening. The distribution is considered pathological by

329 the method. This likely means that the scatter is not either of geomagnetic in origin or from

330 sedimentary flattening. Another possible explanation would be either an error in age or a

331 remagnetization of the sediments in the Cenozoic. New radiometric and paleomagnetic data

332 are needed to decide between these hypotheses.

\section{Conclusion}

43 sites (278 specimens), sampled in Cenozoic and Cretaceous horizons all over Egypt, have been paleomagnetically studied. The analysis has been hampered by the very common occurrence of secondary components acquired by isothermal process, likely during lightning strikes, especially along the Red Sea coast. New mean paleomagnetic directions have been 
obtained from 26 individual sites, and 8 new mean poles proposed (2 Cenozoic and 6 Cretaceous) and compared with the Master Polar Wander Paths proposed for South Africa. The Cretaceous poles from Toshki, Abu Simbel and Shalaten ST1 are in good agreement with the MPWPs but not the Cretaceous poles from Shalaten ST2 and Abu Shihat, and all our Cenozoic pole positions.

A compilation of all Cenozoic and Cretaceous paleomagnetic data published for Egypt (41 references published between 1973 and 2016) did not help to understand the discrepancy. After a mild selection (kappa >50), the 50 remaining poles (29 Cenozoic poles and 21 Cretaceous poles) present a significant dispersion but mainly a fairly large overlap between the Cenozoic and Cretaceous poles with no obvious correlation between VGPs and ages. In order to check the influence of some of the reasons that could explain that overlap, a compilation was made at the site level for all data with ages ranging from Middle Miocene to Cretaceous. Beside rejection of all results clearly influenced by IRMs, choosing to limit the dispersion at the site level to kappa>50 reduced the occurrence of intermediate components of magnetization. Finally to avoid the over-representation of certain areas, new mean poles have been calculated taking into account all sites available in a given area, for a given period.

The four recalculated sedimentary poles for the Cenozoic describe a coherent evolution toward the present field even though the relation between poles and ages still remains unclear. Averaging the site poles for individual sedimentary levels, with a $10 \mathrm{Ma}$ age windows, give a better definition of the mean poles for the different epochs of the Cenozoic, and allow to propose a new Cenozoic apparent polar wander path for Egypt. The seven new igneous poles fit fairly well the sedimentary data, confirming the reliability of the proposed path. An anticlockwise rotation on the order of $10-15^{\circ}$ is necessary to bring back the Egyptian curve onto the South African MPWP, similar to what have been described by Ibrahim (1999) for the Afar rift. 
The four igneous recalculated poles for the Cretaceous are in good agreement with the

364

78-98 Ma portion of the BC2002's MPWP for South Africa, underlying an upper Cretaceous age for all this volcanic activity. The four sedimentary poles fall close from the Cenozoic portion of BC2002's MPWP, a discrepancy that could be related to inclination flattening and/or error on age and/or remagnetization in the Cenozoic. New radiometric and paleomagnetic data are needed to decide between these hypotheses.

\section{Acknowledgement}

This work was supported through a contribution CNRS-INSU, 2-year PHC IMHOTEP project 20734YC, 2-month postdoctoral fellowship for A.S. from the French MAEE, and the support of NRIAG for fieldwork and travel to France for A.S. The authors wish to acknowledge Pierre Camps's help in the Montpellier laboratory, and to thanks Lisa Tauxe for her very helpful review. 


\section{References}

Abd El-All E.M., 2004. Paleomagnetism and rock magnetism of El-Naga ring complex, South Eastern Desert, Egypt. NRIAG J. Geoph, 3, 17-31.

Abdeldayem, A.L., 1999. Palaeomagnetism of some Cenozoic sediments, Cairo-Fayum area, Egypt. Phys. Earth Planet. Inter., 110, 71-82.

Abdeldayem, A.L., 1996. Paleomagnetism of some Miocene rocks, Qattara depression, western desert, Egypt. J. Afr. Earth Sci., 22, 525-533.

Besse, J., Courtillot, V., 2002. Apparent and true polar wander and the geometry of the geomagnetic field over the last 200 Myr. J. Geophys. Res, 107, doi:10.1029 /2000JB000050.

Bosworth, W., Stockli, D.F., Helgeson, D.E., 2015. Integrated outcrop, 3D seismic, and geochronologic interpretation of Red Sea dike-related deformation in the Western Desert, Egypt - The role of the 23 Ma Cairo “mini-plume’”. J. Afr. Earth Sci., 109, $107-119$.

Bosworth, W., Stockli, D.F., 2016. Early magmatism in the greater Red Sea rift: timing and significance. Can. J. Earth Sci., 53, 1158-1176, dx.doi.org/10.1139/cjes-2016-0019.

DeMets, C., Merkouriev, S., 2016. High-resolution estimates of Nubia-Somalia plate motion since 20 Ma from reconstructions of the Southwest Indian Ridge, Red Sea and Gulf of Aden. Geophys. J. Int., 207, 317-332.

El Shazly, E.M., Krs, M., 1973. Paleogeography and paleomagnetism of the Nubian Sandstone, Eastern Desert of Egypt, Geol. Rundschau, 62, 212-225.

El-Shayeb H., El-Hemaly I.A., Abdel Aal E., Saleh A., Khashaba A., Odah H., Mostafa R., 2013. Magnetization of three Nubia Sandstone formations from Central Western Desert of Egypt. NRIAG Journal of Astronomy and Geophysics, 2, 1, 77-87. ISSN 2090-9977, https://doi.org/10.1016/j.nrjag.2013.06.011. 
Endress C., Furman T., Abu El-Rus M.A., Hanan B.B., 2011. Geochemistry of 24 Ma basalts from NE Egypt: source components and fractionation history. In The Formation and Evolution of Africa: A Synopsis of 3.8 Ga of Earth History. Van Hinsbergen, D. J. J., Buiter, S. J. H., Torsvik, T. H., Gaina, C. andWebb, S. J. (eds). Geological Society, London, Special Publications, 357, 265-283. DOI: 10.1144/SP357.14 0305$8719 / 11 / \$ 15.00$

Hussain A.G., Aziz Y., 1983. Paleomagnetism of Mesozoic and Tertiary rocks from East El Owenat area, southwest Egypt, J. Geophys. Res., 88, 3523-3529.

Hussain A.G., Soffel H., Schult A., 1980. Paleomagnetism of the Quatrani basalts, western desert. Egypt, Acad Sc. Res. Tech., 224, 1-9.

Hussain A.G., Schult A., Soffel H., 1979. Palaeomagnetism of the basalts of Wadi Abu Tereifiya, Mandisha and dioritic dykes of Wadi Abu Shihat, Egypt. Geophys. J. Royal Astronomic. Soc., 56, 55-61.

Hussain A.G., 1977. Magnetization of some sedimentary rocks units in Bahariya area, western desert, Egypt. Helwan Obs Bull, 141, 1-2.

Hussain A.G., Schult A., Soffel H. and Fahim M., 1976a . Magnetization and paleomagnetism of Abu Zaabal and Abu Rawash basalts (Egypt). Bull. Helwan Inst Astro Geo, 134, 115.

Hussain A.G., Schult A., Soffel H., Fahim M., 1976b. Magnetization of the Nubian sandstone of Aswan area, Idfu-Mersa Alam and Qena-Safaga districts, Egypt, Bul Helwan Inst. Astro Geo., 133, 1-14.

Ibrahim, E.H., 1999. Paleomagnetism and the Afro-Arabian rift system. Egyptian J. Geol., 42, 257-272. 
Kappelman J., Simons, E.L., and Swisher III C.C., 1992. New Age Determinations for the Eocene-Oligocene Boundary Sediments in the Fayum Depression, Northem Egypt. The Journal of Geology, 100, 647- 6681.

Kent D.V., Dupuis C., 2003, Paleomagnetic study of the Paleocene-Eocene Tarawan chalk and Esna shale: dual polarity remagnetizations of Cenozoic sediments in the Nile Valley (Egypt). MicroPal., 49, 139-146.

Lattard D., Engelmann R., Kontny A. and Sauerzapf U., 2006. Curie temperatures of synthetic titanomagnetites in the Fe-Ti-O system. Reassessment of some methodological and crystal chemical effects. J. Geophys. Res., 111, B12S28.

Lotfy H.I., Odah H.H., 2015. Paleo-tectonic positions of Northeast Africa during CretaceousPaleocene: Paleomagnetic study on East Gilf Kebir Plateau basalts [59Ma], Southwestern Desert, Egypt, NRIAG J. Geophys., 4, 32-43.

Lofty H.I., 2011. Active concomitant counterclockwise rotation and northwards translation of Africa during the Albian-Campanian time: a paleomagnetic study on the Wadi Natash alkaline province (104-78 Ma), southeastern desert, Egypt, Palaeogeography, Palaeoclimatology, Palaeoecology, 310, 176-190.

Lofty H.I., Van der Voo R., 2007. Tropical northeast Africa in the middle-late Eocene: Paleomagnetism of the marine-mammals sites and basalts in the Fayum province, Egypt. J. Afr. Earth Sc., 47, 135-152.

Lofty H.I., Abd El-All E., 2003. Paleomagnetic study on the middle Eocene limestone, the Tertiary basalt and the iron mineralization, west El Minia, Egypt. Annals Geol Surv Egypt, 26, 507-528.

Lofty H.I., Odah H.H., 1998. Paleomagnetic differentiation of two Tertiary basaltic episodes in northern Egypt during the Late Eocene and early Miocene, in northeast Egypt: Hint 
of petrochemical and petrologic diversity, Bull. Fac. Sci Geology, Assiut Univ., 27, 301-320.

453

454

455

456

457

458

459

460

461

462

463

464

465

466

467

468

469

470

471

472

473

Lofty H.I., Van der Voo R., Hall M., Kamel O.A., Abdel Aal A.Y., 1995. Paleomagnetism of Early Miocene basalt eruptions in the areas east and west of Cairo, J. Afr. Earth Sci., 21, 407-419.

Lurcock, P. C. and G. S. Wilson, 2012. PuffinPlot: A versatile, user-friendly program for paleomagnetic analysis, Geochemistry, Geophysics, Geosystems, 13, Q06Z45, doi:10.1029/2012GC004098.

Meineissy M.Y., 1990. Vulcanicity in The Geology of Egypt, Said, R. eds, 157-172, Balkema, Rotterdam, Brookfield.

Mohamed F.H., 2001. The Natash alkaline volcanic field, Egypt: geochemical and mineralogical inferences on the evolution of a basalt to rhyolite eruptive suite. Journal of Volcanology and Geothermal Research, 105, 291-322.

Mostafa R., Khashaba A., El-Hemaly I.A., Takla E.M., Abdel Aal E., and Odah H., 2016.

1st paleomagnetic investigation of Nubia Sandstone at Kalabsha, south Western Desert of Egypt. NRIAG J. Geophys., 5, 254-262.

Niazi H., and Mostafa M.O., 2002. A paleomagnetic study of the Tertiary basaltic lava flows around Wadi Hudayn Shalatayn area, south Eastern Desert, Egypt. Annals Geol Survey Egypt, 25, 429-442.

Odah H., 2004. Paleomagnetism of the Upper Cretaceous Bahariya Formation, Bahariya Oasis, Western Desert, Egypt. J. Appl. Geophys., 3, 2, 177-187.

Perrin M., Saleh A., Alva-Valdivia L.M., 2009. Cenozoic and Mesozoic basalts from Egypt: a preliminary survey with a view to paleointensity. Earth Planet. Sc., 61, 51-60. 
Ressetar R., Nairn A.E.M., Monrad J.R., 1981. Two phases of Cretaceous-Tertiary magmatism in the eastern desert of Egypt: paleomagnetic, chemical and K-Ar evidence. Tectonophysics, 73, 169-193.

Reynolds R.L., , 1982. Paleomagnetic research in Egypt. Report Geol. Surv. Egypt, 22, 1-12.

Saradeth S., Soffel H., Schult A., 1987. Palaeomagnetism of sedimentary rocks of the uppermost Cretaceous from the oases of Dakhla and Kharga in the western desert of Egypt. J. Geophys., 61, 64-66.

Schult A., Hussain A.G., Soffel H.C., 1981. Paleomagnetism of Upper Cretaceous Volcanics and Nubian Sandstones of Wadi Natash, SE Egypt and implications for the Polar Wander Path for Africa in the Mesozoic. J. Geophys., 50, 16-22.

Schult A., Soffel H.C., Hussain A.G., 1978. Palaeomagnetism of Cretaceous Nubian Sandstone, Egypt. J. Geophys., 44, 333-340.

Tauxe, L., Kodoma, K.P., Kent, D.V., 2008. Testing corrections for paleomagnetic inclination error in sedimentary rocks: a comparative approach. Phys. Earth Planet. Inter., 169, 152165.

Tauxe, L., R. Shaar, L. Jonestrask, N. L. Swanson-Hysell, R. Minnett, A. A. P. Koppers, C. G. Constable, N. Jarboe, K. Gaastra, L. Fairchild, 2016. PmagPy: Software package for paleomagnetic data analysis and a bridge to the Magnetics Information Consortium (MagIC) Database, Geochem. Geophys. Geosyst., 17, 2450- 2463, doi:10.1002/2016GC006307.

Torsvik, T.H., Muller R.D., Van der Voo, R., Steinberger, B., Gaina, C, 2008. Global Plate Motion Frames: Toward A Unified Model. Reviews of Geophysics, 46, RG3004.

Vahle C., Kontny A., Gunnlaugsson H.P. Kristjánsson L., 2007. The Stardalur magnetic anomaly revisited - new insights into a complex cooling and alteration history. Phys. Earth Planet. Inter., 164, 119-141. 
Table 1. Mean paleomagnetic results by site and by area. P: Polarity (R/N: Reverse/Normal); D/I: Declination/Inclination; B/N: number of sites/samples; $\left(\alpha_{95}, \mathrm{k}\right) /\left(\mathrm{A}_{95}, \mathrm{~K}\right)$ : Fisher statistic for the direction/pole; ${ }^{\circ} \mathrm{N} /{ }^{\circ} \mathrm{E}$ : Latitude/Longitude; P: polarity (Normal/Reverse).

Table 2. Published Cenozoic and Cretaceous paleomagnetic poles for Egypt. ${ }^{\circ} \mathrm{N} /{ }^{\circ} \mathrm{E}$ : Latitude/Longitude; B/N: number of sites/samples; $\left(\mathrm{A}_{95}, \mathrm{~K}\right)$ : Fisher statistic.

Table 3. (Supplementary Material) Compilation of all site level paleomagnetic poles obtained from Cenozoic and Cretaceous rocks from Egypt. ${ }^{\circ} \mathrm{N} /{ }^{\circ} \mathrm{E}$ : Latitude/Longitude; N: number of samples; $\left(\mathrm{A}_{95}, \mathrm{~K}\right)$ : Fisher statistic; R: Rocks (I/S/O: Igneous/Sediments/Iron ore).

Table 4. Recalculated poles for the Cenozoic and Cretaceous of Egypt. Acc: Acronym; ${ }^{\circ} \mathrm{N} /{ }^{\circ} \mathrm{E}$ : Latitude/Longitude; B: number of sites; $\left(\mathrm{A}_{95}, \mathrm{~K}\right)$ : Fisher statistic.

\section{FIGURE CAPTIONS}

Figure 1. Cenozoic (circle) and Cretaceous (square) paleomagnetic sites for Egypt. Light/dark: literature/our sites (this study \& Perrin et al, 2009), dots: cities.

Figure 2. Heating/cooling cycles of representative $\mathrm{K}-\mathrm{T}$ experiments.

Figure 3. Equal-area plot, orthogonal diagram, and demagnetization curve for representative samples: a) 2 components of magnetization; b) single component of magnetization; c) partial IRM remagnetization. Open/full squares: vertical/horizontal projections on the orthogonal plots and negative/positive inclination on the equal area plots. Red/black symbols: selected/not selected demagnetization step. 
Figure 4. Equal-area plot with ChRM directions per area. Open/full circles: negative/positive inclination.

Figure 5. Summary of our paleomagnetic results: a) ChRMs per site, b) ChRMs per area, and c) VGPs compared to BC2002 (red) and T2008 (yellow) MPWPs for South Africa.

Figure 6. Paleomagnetic poles published for Egypt (Table 2), compared with the BC2002 MPWP: a) without selection; and b) only poles with kappa larger than 50. Blue/red: Cenozoic /Cretaceous poles. Light/dark: literature/our sites (this study \& Perrin et al, 2009).

Figure 7. Cenozoic poles at the site level for Egypt: a) temporal distribution, b) all site poles, c) Shalaten poles, d) selected poles (kappa>50), e) recalculated poles (Table 4), new Cenozoic path for Egypt (dashed arrow) and BC2002 MPWP (full line). Dark/Light A 95 circles: Igneous/sediments.

Figure 8. Cretaceous poles at the site level for Egypt: a) all site poles, b) selected poles (kappa>50), c) recalculated poles (Table 4) compared to BC2002 MPWP (full grey line). Dark/Light $\mathrm{A}_{95}$ circles: Igneous/sediments. 


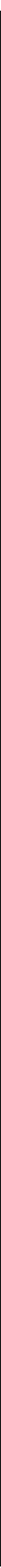

Figure 1 
Figure

Cliqk here to download Figure: Eigzeps

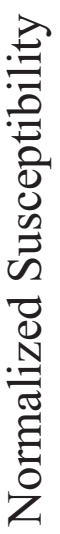

0,8

0,6

$-0,4$

a) Abu Shihat

$\begin{array}{llllll}0 & 200 & 400 & 600 & 800^{\circ} \mathrm{K} & 0\end{array}$

$0,2 \quad$ b) Shalaten
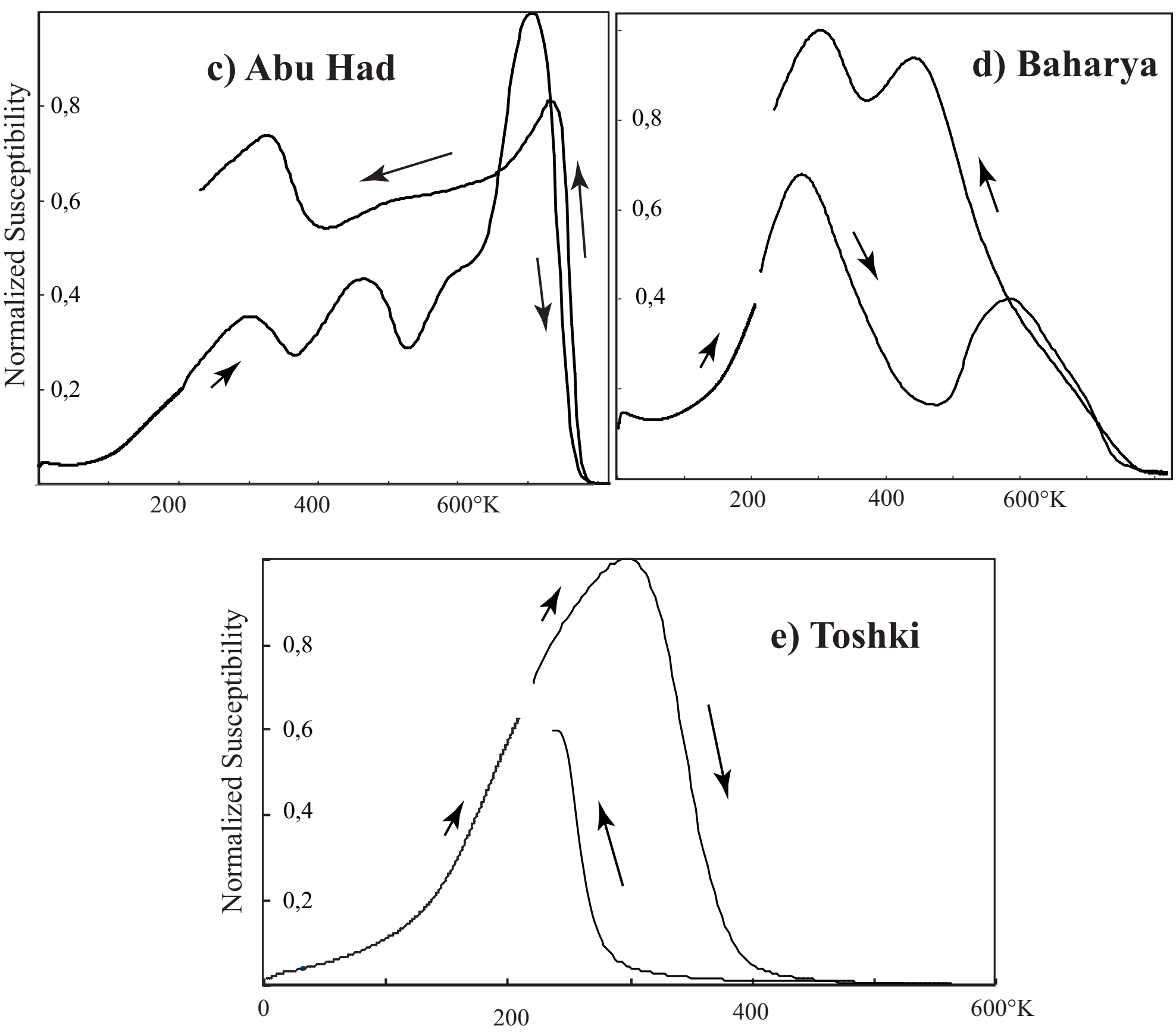

Figure 2 


\section{Figure}

Click here to down'loád Figure: Fiǵ3 eps

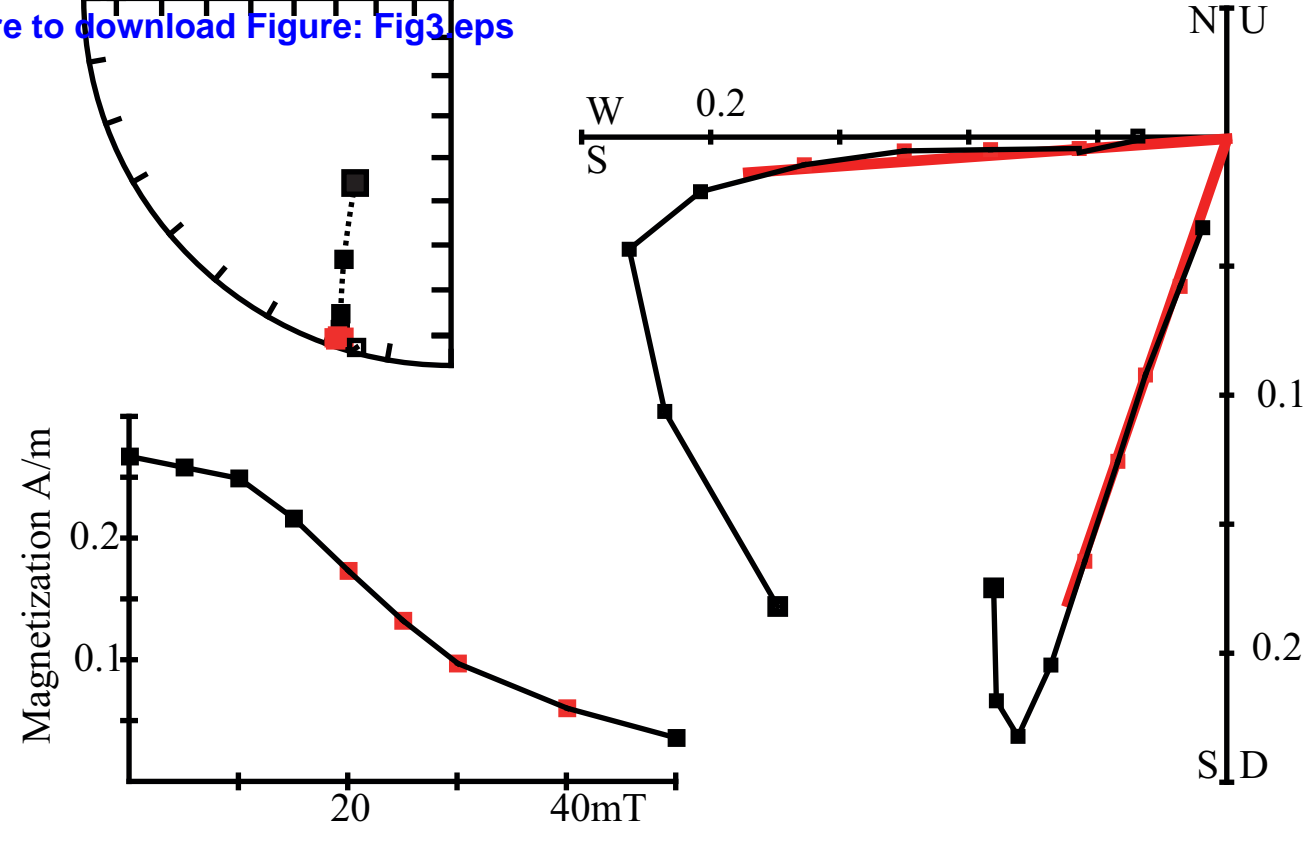

a)
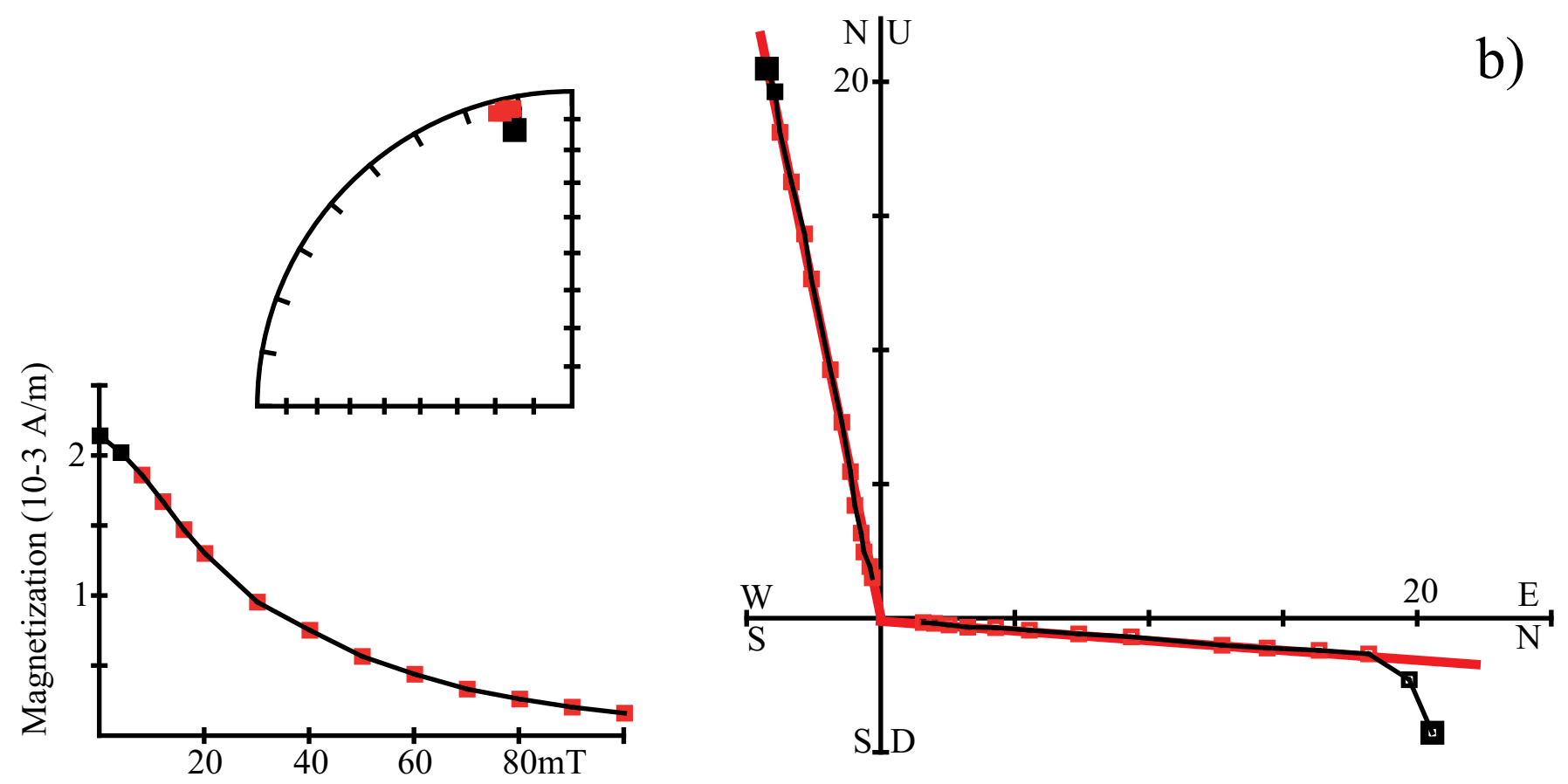

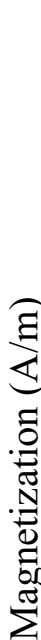
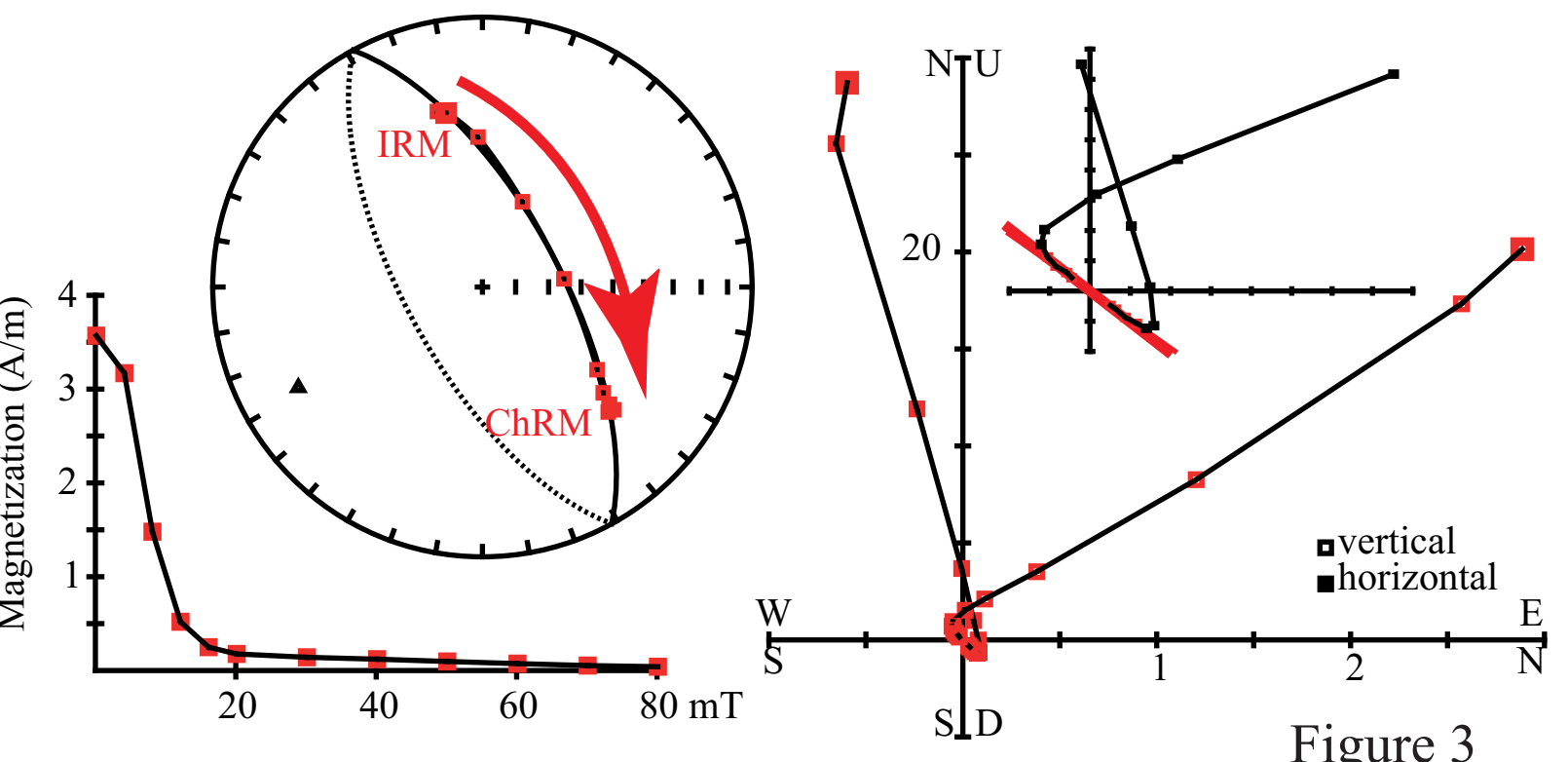

c)

Figure 3 

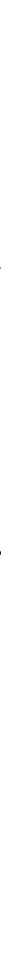

Figure 4 


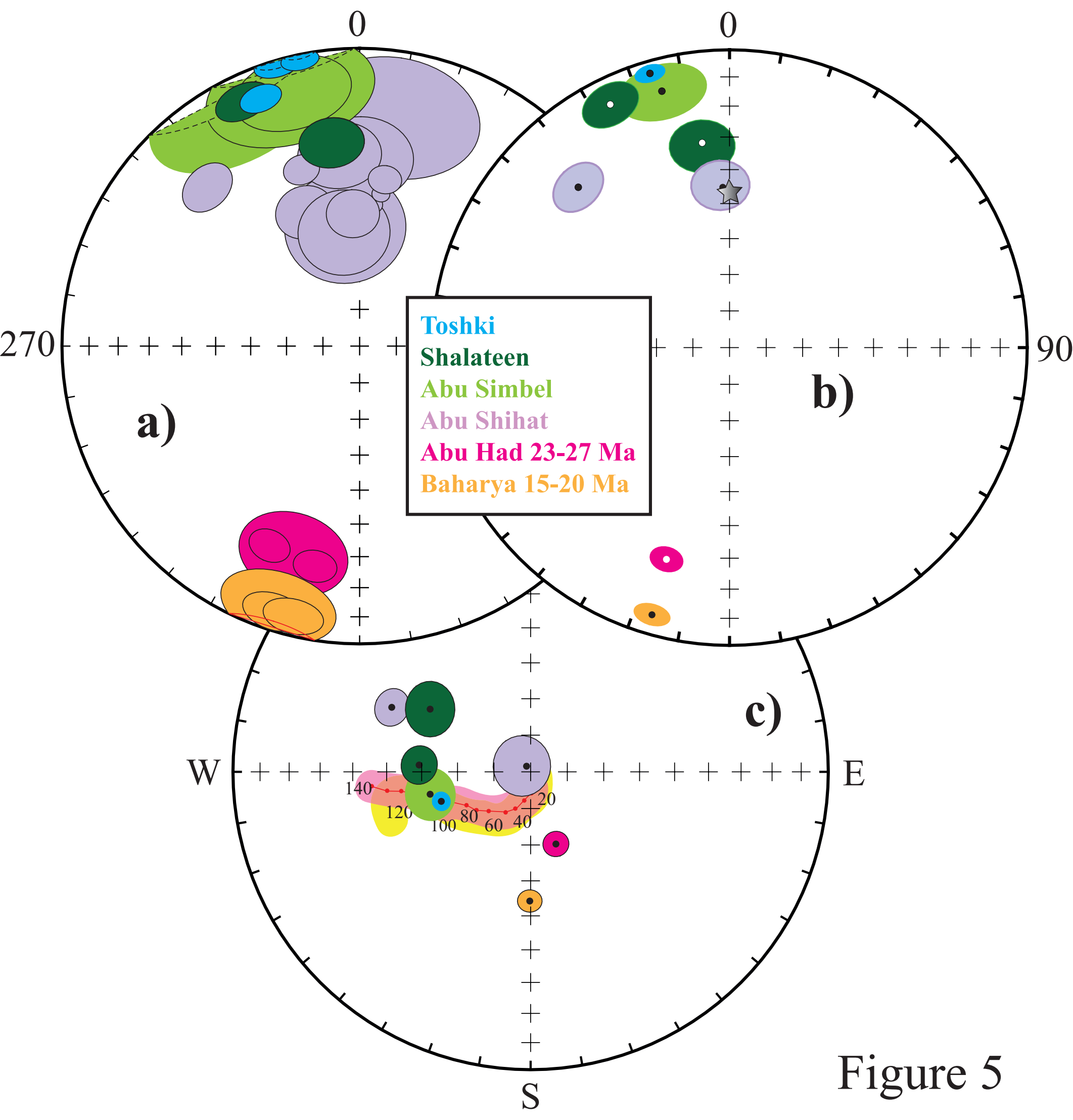




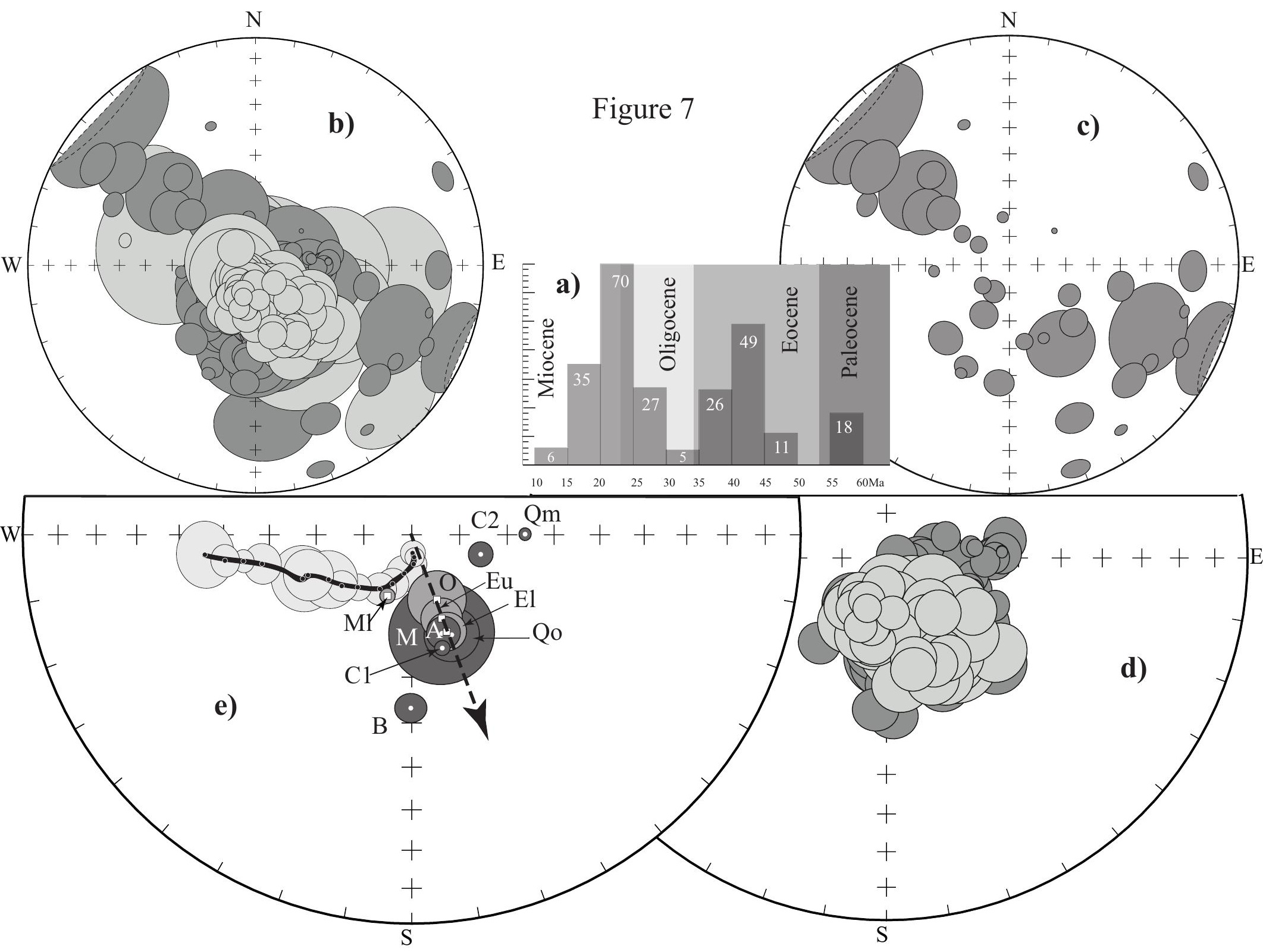




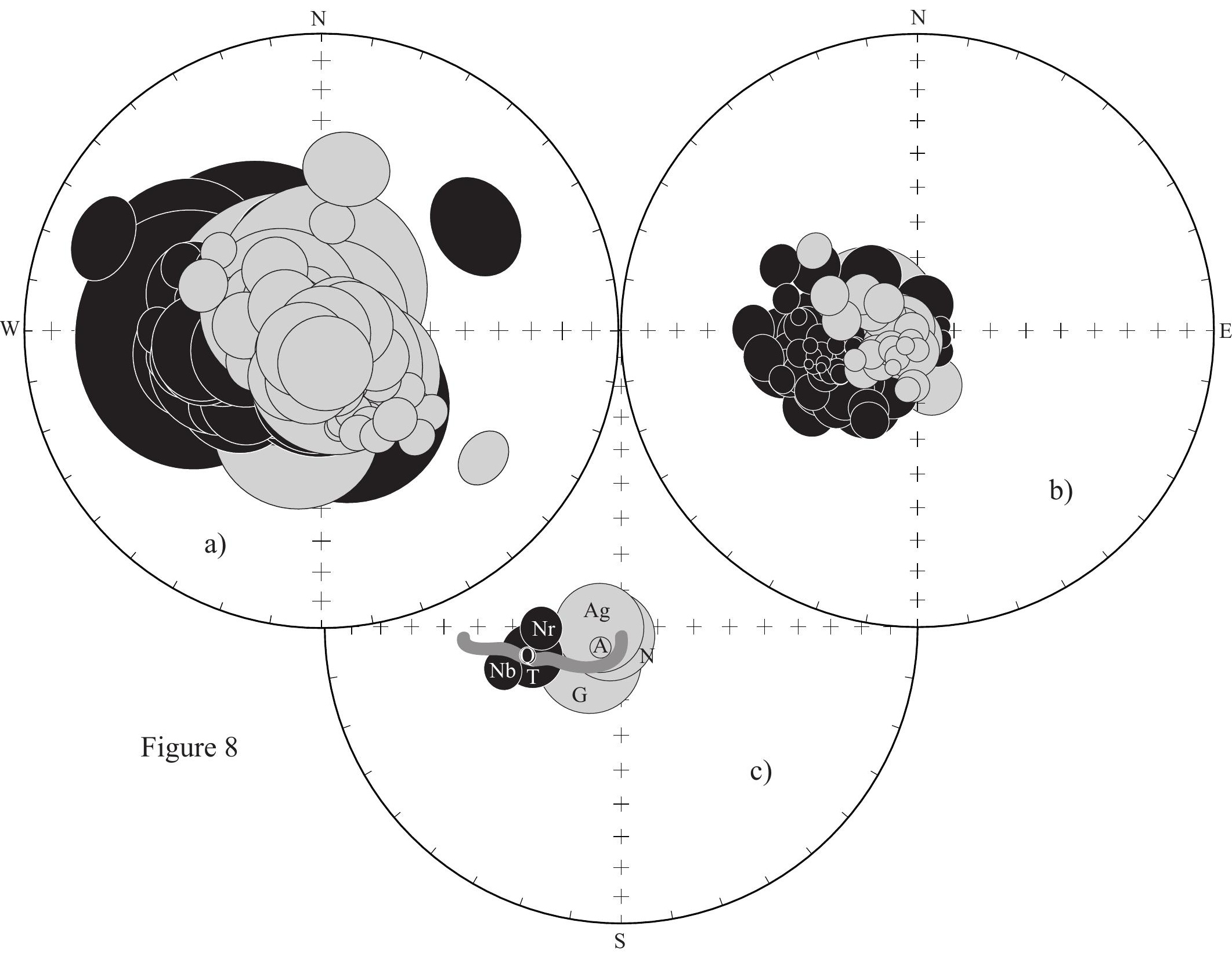




\begin{tabular}{|c|c|c|c|c|c|c|c|c|c|c|c|c|}
\hline \multirow{2}{*}{ Area } & \multirow{2}{*}{$\mathrm{P}$} & \multicolumn{7}{|c|}{ Mean direction } & \multicolumn{4}{|c|}{ Pole } \\
\hline & & Site & B & $\mathrm{N}$ & D & I & $\alpha_{95}$ & $\mathrm{k}$ & ${ }^{\circ} \mathrm{E}$ & & $\mathrm{J} \mathrm{A}_{95}$ & $\mathrm{~K}$ \\
\hline \multirow{5}{*}{ Baharya } & \multirow{5}{*}{$\mathrm{R}$} & BH1 & & 8 & 198 & 7 & 6.6 & 72 & & & & \\
\hline & & $\mathrm{BH} 2$ & & 8 & 194 & 7 & 6.3 & 78 & & & & \\
\hline & & BH3 & & 4 & 197 & 9 & & 57 & & & & \\
\hline & & $\mathrm{RH}$ & & 20 & 196 & 7 & 3.8 & 75 & 180 & & \begin{tabular}{|l|}
4.2 \\
\end{tabular} & 108 \\
\hline & & DП & 3 & & 196 & 8 & & $\mid 1101$ & & & & \\
\hline \multirow{5}{*}{$\begin{array}{l}\text { Abu } \\
\text { Had }\end{array}$} & \multirow{5}{*}{$\mathrm{R}$} & AH1 & & $10 \mid$ & 192 & -26 & 5.1 & 92 & & & & \\
\hline & & $\mathrm{AH} 2$ & & 4 & 198 & -27 & & 51 & & & & \\
\hline & & AH4 & & 6 & 204 & -28 & 5.0 & 179 & & & & \\
\hline & & $\Delta \mathrm{H}$ & & 20 & 197 & -27 & 3.9 & 72 & 161 & 69 & 3.5 & 86 \\
\hline & & AII & 3 & & 198 & -27 & & 192 & & & & \\
\hline \multirow{2}{*}{ Shalaten } & \multirow{2}{*}{$\mathrm{R}$} & ST1 & & 8 & 335 & 10 & 6.1 & 83 & $|273|$ & $\mid 59$ & $|4.9|$ & $\mid 131$ \\
\hline & & \begin{tabular}{|l|} 
ST2 \\
\end{tabular} & & 7 & 352 & 32 & \begin{tabular}{|l|}
7.8 \\
\end{tabular} & 61 & 302 & & 77.2 & \begin{tabular}{|l|l}
72 \\
\end{tabular} \\
\hline \multirow{5}{*}{ Toshki } & \multirow{5}{*}{$\mathrm{N}$} & TK1 & & 9 & 344 & 2 & 4.7 & 123 & & & & \\
\hline & & TK2 & & 9 & 338 & 11 & 4.6 & 125 & & & & \\
\hline & & TK3 & & 10 & 348 & 2 & 3.8 & 159 & & & & \\
\hline & & \multirow{2}{*}{ TK } & & 28 & 344 & 5 & 3.1 & 79 & 252 & 64 & $\begin{array}{l}+2.5 \\
\end{array}$ & 122 \\
\hline & & & 3 & & 343 & 5 & & 119 & & & & \\
\hline \multirow{4}{*}{$\begin{array}{c}\text { Abu } \\
\text { Simbel }\end{array}$} & \multirow{4}{*}{$\mathrm{N}$} & AS1 & & $|10|$ & 345 & $\mid 13$ & |\#\# & 15 & & & & \\
\hline & & AS2 & & 7 & 345 & 12 & \#\#\# & 12 & & & & \\
\hline & & AS3 & & 12 & 333 & -9 & \#\#\# & 6 & & & & \\
\hline & & AS & & 29 & 340 & 4 & \#\#\# & 8 & 258 & & \begin{tabular}{|l|l|}
27.0 \\
\end{tabular} & 16 \\
\hline \multirow{14}{*}{$\begin{array}{c}\text { Abu } \\
\text { Shihat }\end{array}$} & \multirow{14}{*}{$\mathrm{N}$} & SH1 & & 4 & 354 & 35 & & 82 & & & & \\
\hline & & SH2 & & 5 & 338 & 50 & 7.6 & 102 & & & & \\
\hline & & SH4 & & 4 & 352 & 58 & & 59 & & & & \\
\hline & & SH5 & & 5 & 342 & 37 & 4.5 & 294 & & & & \\
\hline & & SH8 & & 6 & 6 & 50 & 2.4 & 762 & & & & \\
\hline & & $\begin{array}{ll}\text { SH9 } \\
\end{array}$ & & 6 & 357 & 53 & 6.9 & 94 & & & & \\
\hline & & SH11 & & 6 & 8 & 47 & 2.3 & 845 & & & & \\
\hline & & SH12 & & 6 & 9 & 43 & 4.2 & 259 & & & & \\
\hline & & SH13 & & 6 & 0 & 37 & \#\#\# & 28 & & & & \\
\hline & & SH15 & & 3 & 353 & 57 & & 61 & & & & \\
\hline & & SH16 & & 4 & 8 & 22 & & 22 & & & & \\
\hline & & \multirow{2}{*}{ SH } & & 55 & 358 & 45 & 3.5 & 31 & & & & \\
\hline & & & 11 & & 357 & 45 & 7.5 & 38 & 323 & & \begin{tabular}{|l|l|}
7.2 \\
\end{tabular} & \begin{tabular}{|l|}
41 \\
\end{tabular} \\
\hline & & SH10 & & 6 & 316 & 27 & 6.6 & 105 & 295 & & \begin{tabular}{|l|l|}
34.9 \\
\end{tabular} & 186 \\
\hline
\end{tabular}




\section{Click here to download Table: Table2.xIsx}

\begin{tabular}{|c|c|c|c|c|c|c|c|c|c|c|c|}
\hline \multirow{2}{*}{ feren } & \multicolumn{3}{|c|}{ Site } & \multicolumn{2}{|c|}{ Age } & \multirow{2}{*}{ B } & & \multicolumn{4}{|c|}{ Pole } \\
\hline & Locality & ${ }^{\circ} \mathrm{N}$ & ${ }^{\circ} \mathrm{E}$ & $\mathrm{Ma}$ & \pm & & & ${ }^{\circ} \mathrm{N}$ & ${ }^{\circ} \mathrm{E}$ & $A_{95}$ & $\mathrm{~K}$ \\
\hline 973 & swan & \#\#\# & \#\#\# & 88 & 8 & $J$ & 12 & 75 & 203 & 9 & 20 \\
\hline & & & \#\#\# & 8 & 8 & & 4 & 64 & 218 & & \\
\hline & & $\#$ & \#\#\# & 23 & 4 & 1 & & 76 & 70 & 3 & $\# \#$ \\
\hline & & \# & \#\#\# & 28 & 5 & 1 & 17 & 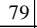 & 81 & 6 & \#\# \\
\hline & & \#\# & \#\#\# & 83 & $\#$ & 9 & & 81 & 200 & 9 & \\
\hline & & \# & \#\#\# & 83 & $\#$ & 10 & & 3 & 311 & 10 & 126 \\
\hline & & \#\#\# & \#\#\# & 44 & $\#$ & 7 & & 84 & 163 & 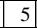 & $\# \#$ \\
\hline & & \#\#\# & \#\#\# & 83 & $\#$ & 18 & $\# \#$ & 80 & 227 & & \\
\hline & & \#\#\# & \#\#\# & 17 & $\#$ & 2 & 30 & 58 & \begin{tabular}{|l|}
187 \\
\end{tabular} & 8 & \\
\hline & & \#\#\# & \#\#\# & 44 & 4 & 6 & \#\# & 69 & 189 & 5 & \#\# \\
\hline & ih & \#\#\# & \#\#\# & \#\# & $\#$ & 4 & 30 & 45 & 273 & 34 & \\
\hline & & \#\#\# & \#\#\# & 25 & 2 & 15 & 41 & 64 & 87 & 1 & $\pi$ \\
\hline & gro & \#\#\# & \#\#\# & 20 & $\#$ & 7 & 60 & 68 & \begin{tabular}{|l|}
102 \\
\end{tabular} & 12 & 27 \\
\hline & & \#\#\# & \#\#\# & 81 & $\#$ & 16 & 92 & 63 & 252 & 2 & \#\# \\
\hline & & \#\#\# & \#\#\# & 83 & 5 & 5 & 24 & 76 & 228 & 15 & 26 \\
\hline & & \#\# & \#\#\# & 88 & 6 & 4 & 1 & 61 & 238 & 6 & \#\# \\
\hline & & \#\#\# & \#\#\# & \begin{tabular}{|l|}
89 \\
\end{tabular} & 0 & 6 & 16 & 59 & 266 & 10 & 44 \\
\hline & & & & 26 & 4 & 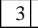 & & 72 & 81 & 11 & \#\# \\
\hline & & \#\#\# & \#\#\# & 93 & 7 & 15 & $\# \#$ & 69 & 258 & 7 & 31 \\
\hline & & \#\#\# & \#\#\# & 36 & 2 & \begin{tabular}{|l|}
9 \\
\end{tabular} & & 84 & \begin{tabular}{|l|}
139 \\
\end{tabular} & 7 & 6 \\
\hline & & $\#$ & \#\#\# & 93 & 7 & \begin{tabular}{l|l}
5 \\
\end{tabular} & $\# \#$ & 83 & 231 & 0 & 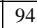 \\
\hline & & \# & $\# \#$ & 23 & & & & 68 & 92 & 3 & \# \\
\hline & & \#\#\# & $\# \#$ & 34 & $\#$ & 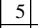 & \# & 74 & 160 & 0 & 64 \\
\hline & & \#\#\# & \#\# & 83 & $\#$ & 10 & \#\# & 68 & 269 & 10 & 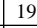 \\
\hline & & \#\#\# & \#\#\# & 83 & $\#$ & 7 & 82 & 77 & 258 & 9 & 7 \\
\hline & & \# & \#\#\#\# & 68 & 3 & 7 & $\# \#$ & 82 & 225 & 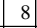 & 60 \\
\hline & & \# & \#\#\#\# & 18 & 0 & 16 & \# & 76 & 111 & & \#\# \\
\hline & & $\#$ & \#\#\# & 23 & 0 & 11 & $\# \#$ & 66 & 167 & 2 & \#\# \\
\hline & & $\# \#$ & \#\#\# & 14 & 9 & 11 & 64 & 77 & 198 & - & \#\# \\
\hline & & \#\# & \#\#\# & 21 & 1 & \begin{tabular}{|l|}
66 \\
\end{tabular} & & 76 & \begin{tabular}{|l|}
107 \\
\end{tabular} & 3 & 27 \\
\hline & & $\#$ & $\# \#$ & 23 & & 43 & & 66 & 164 & 4 & 31 \\
\hline & & \#\# & \#\#\# & 20 & 3 & \begin{tabular}{|l|}
27 \\
\end{tabular} & & 79 & \begin{tabular}{|l|}
119 \\
\end{tabular} & 7 & 18 \\
\hline & & \#\#\# & \#\#\# & 36 & 2 & 58 & & 64 & 162 & 3 & 26 \\
\hline & & \#\#\# & \#\#\# & 24 & 0 & 2 & 15 & 67 & 98 & 19 & \#\# \\
\hline & & \#\#\# & \#\#\# & 25 & 2 & 9 & 64 & 80 & \begin{tabular}{|l|}
151 \\
\end{tabular} & 6 & 74 \\
\hline & Iok & \#\#\# & \#\#\# & 45 & $\#$ & 11 & 91 & 78 & 163 & 4 & \#\# \\
\hline & Shal & \#\#\# & & 34 & $\#$ & 16 & 84 & 83 & \begin{tabular}{|l|}
190 \\
\end{tabular} & 11 & 12 \\
\hline & & & & 34 & $\#$ & 4 & 22 & 50 & 22 & 10 & 84 \\
\hline & & & & 34 & $\#$ & 5 & & 34 & 305 & 16 & 25 \\
\hline & & & & 34 & $\#$ & 0 & & 25 & 112 & 12 & 23 \\
\hline & & & & 50 & $\#$ & 2 & 71 & 88 & \begin{tabular}{|l|}
159 \\
\end{tabular} & 3 & 45 \\
\hline & & & & 6 & 3 & 5 & 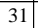 & 8 & . & $\gamma$ & 5 \\
\hline & & & & 43 & 5 & \begin{tabular}{l|l|}
9 &
\end{tabular} & 51 & 61 & \begin{tabular}{|l|}
156 \\
\end{tabular} & 0 & \begin{tabular}{|l|}
71 \\
\end{tabular} \\
\hline & & & \# & \#\# & $\#$ & 14 & $\# \#$ & 68 & \begin{tabular}{|l|}
268 \\
\end{tabular} & 5 & 61 \\
\hline & & \# & $\# \#$ & 95 & 5 & 14 & 70 & 71 & 151 & & \\
\hline & & $\#$ & \#\# & 29 & 6 & 13 & 87 & 68 & \begin{tabular}{|l|}
158 \\
\end{tabular} & & \\
\hline & & \#\# & \#\# & 42 & 8 & 38 & \#\# & 70 & \begin{tabular}{|l|}
159 \\
\end{tabular} & 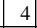 & 55 \\
\hline & & & \# & 23 & 1 & 2 & 26 & 70 & 83 & 1 & \# \\
\hline & & & $\# \#$ & 25 & 2 & 2 & 17 & 66 & 90 & 3 & \# \\
\hline & & & \#\#\# & 82 & 4 & 10 & 61 & 67 & 229 & & 96 \\
\hline & & 蝴 & \#\#\# & \#\# & 7 & 12 & 68 & 55 & 250 & $\rho$ & 84 \\
\hline & & 耕 & \#\#\# & 92 & 2 & 8 & 44 & 86 & 223 & 9 & 41 \\
\hline & & \#\#\# & \#\#\# & 83 & \# & 5 & 38 & 66 & 141 & 9 & 78 \\
\hline & & \#\#\# & \#\#\# & \#\# & $\#$ & \begin{tabular}{|l|l|}
11 \\
\end{tabular} & 96 & 78 & \begin{tabular}{|l|}
294 \\
\end{tabular} & & \\
\hline & ilf Keb & \#\#\# & \#\#\# & 59 & 2 & 13 & 84 & 72 & \begin{tabular}{|l|}
204 \\
\end{tabular} & 5 & \\
\hline & & & & 83 & 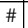 & 4 & 57 & \begin{tabular}{|l|}
83 \\
\end{tabular} & \begin{tabular}{|l|}
283 \\
\end{tabular} & 5 & \\
\hline & & \#\#\# & \#\#\# & \begin{tabular}{|l|}
83 \\
\end{tabular} & H & & 75 & 78 & 280 & & \\
\hline
\end{tabular}


Click here to download Table: Table4.xIsx

\begin{tabular}{|c|c|c|c|c|c|c|c|c|c|}
\hline \multicolumn{2}{|l|}{ Site } & \multicolumn{3}{|c|}{ Age } & \multicolumn{5}{|c|}{ Pole } \\
\hline Name & Acc & & $\mathrm{Ma}$ & \pm & B & ${ }^{\circ} \mathrm{E}$ & ${ }^{\circ} \mathrm{N}$ & $\mathrm{A}_{95}$ & $\mathrm{~K}$ \\
\hline Baharya igneous & B & & 18 & 3 & 3 & 180 & 54 & 3.2 & 108 \\
\hline Cairo igneous & $\mathrm{C} 1$ & & 21 & 2 & 11 & 164 & 66 & 1.6 & 815 \\
\hline Cairo igneous & $\mathrm{C} 2$ & & 23 & 5 & 23 & 103 & 75 & 2.6 & 140 \\
\hline Qatrani igneous & Qm & & 23 & 3 & 7 & 88 & 66 & 1.3 & 2035 \\
\hline Minia igneous & $\mathrm{Mi}$ & & 26 & 3 & 4 & 162 & 69 & 10.9 & 72 \\
\hline Qatrani igneous & Qo & & 29 & 6 & 13 & 157 & 68 & 5.7 & 53 \\
\hline Abu Had igneous & A & ن & 45 & 11 & 3 & 161 & 69 & 3.5 & 86 \\
\hline Qatara sediments & $\mathrm{Qa}$ & & 18 & 6 & 9 & 202 & 77 & 1.6 & 983 \\
\hline Qatrani sediments & Q & & 37 & 8 & 41 & 158 & 71 & 3.0 & 55 \\
\hline Minia sediments & Mi & & 43 & 5 & 5 & 159 & 60 & 8.4 & 84 \\
\hline Mokatam sediments & Mo & & 45 & 11 & 7 & 162 & 77 & 6.2 & 96 \\
\hline Qusier basalt & Q & & 81 & 13 & 16 & 253 & 63 & 2.3 & 266 \\
\hline Natash basalt & $\mathrm{Nb}$ & & 104 & 7 & 12 & 250 & 55 & 5.4 & 66 \\
\hline Naga ring complex & $\mathrm{Nr}$ & & 140 & 15 & 12 & 269 & 68 & 5.9 & 55 \\
\hline Toshki basalt & $\mathrm{T}$ & ప & 106 & 40 & 3 & 252 & 64 & 8.7 & 201 \\
\hline Natash sediments & $\mathrm{N}$ & Q & 92 & 2 & 4 & 231 & 86 & 12.3 & 57 \\
\hline Aswan sediments & A & & 83 & 17 & 8 & 225 & 82 & 2.9 & 365 \\
\hline Agag sediments & $\mathrm{Ag}$ & & 92 & 2 & 3 & 267 & 84 & 12.2 & 103 \\
\hline Gifata sediments & G & & 74 & 4 & 3 & 223 & 77 & 14.3 & 75 \\
\hline
\end{tabular}

